\title{
Infant formula for gastro-oesophageal reflux disease
}

\author{
Owens CJW, BScDietetics; Labuschagne IL, BScDietetics; Lombard MJ, PhD \\ Nutrition Information Centre, Stellenbosch University \\ Correspondence to: Cornelia Owens, e-mail: nicus@sun.ac.za \\ Keywords: gastro-oesophageal reflux disease, infant formula, thickened feeding
}

\begin{abstract}
Thickened infant formula is widely used as a first-line treatment for gastro-oesophageal reflux (GOR) in infants. The use thereof remains controversial, and conflicting evidence exists with regards to its efficiency. The safety of anti-reflux formula has been proven, with only a few adverse effects reported, making it safe for infants with mild symptoms of reflux.
\end{abstract}

\section{Introduction}

Gastro-oesophageal reflux (GOR) is the spontaneous movement of gastric content into the oesophagus due to an inappropriate relaxation of the lower oesophageal sphincter. It can occur with or without regurgitation and vomiting, and is a normal physiological process that occurs in many healthy infants. Often reflux occurs in neonates and premature infants, ${ }^{1,2}$ and does not require treatment unless it is accompanied with failure to thrive, respiratory problems and infant discomfort. ${ }^{3}$

By 12-15 months, most GOR cases resolve spontaneously. A small percentage of children have symptoms after two years of age. According to the Montreal global consensus, gastro-oesophageal reflux disease (GORD) results when GOR is associated with symptoms and complications. ${ }^{4}$ These symptoms or complications can include growth faltering, irritability, feeding difficulties, respiratory problems, anaemia due to iron deficiency, and haematemesis. This is a more serious condition, and requires specialised care. ${ }^{5-7}$ No reliable diagnostic test exists, but intraluminal oesophageal pH monitoring can be used. ${ }^{7} \mathrm{GOR}$ and GORD can be diagnosed from the patient's history, a thorough clinical evaluation and appropriate anthropometrical measurements. The patient's history should focus on frequency of regurgitation per day, type of emesis, and volume and frequency of food, especially milk and types of food. ${ }^{8}$

Breastfed vs. formula-fed infants have a similar frequency in physiological GOR, although breastfeed infants have shorter episodes of reflux. Mothers of breastfed infants who present with mild symptoms of reflux should be encouraged to continue breastfeeding. ${ }^{\text {? }}$

The aim of this review is to provide a summary of the latest information available on GOR and GORD regarding the symptoms and treatment of both, as well as available formula, and the role of thickened formula in the treatment of GORD.

\section{Treatment for uncomplicated GOR and GORD}

The aim of treatment is to reduce symptoms, to optimise growth and development, and to prevent further complications. Failure to thrive is a warning sign that GORD exists. ${ }^{2}$ Therefore, regular anthropometric measurements are important to ensure optimal weight gain. ${ }^{7}$ Parental reassurance, support and education can be sufficient management tools..$^{5-7}$

However, formula-fed infants with recurrent episodes of emesis do not necessarily suffer from GOR or GORD, but may suffer from cow's milk protein sensitivity. These infants may benefit from a trial with an extensively hydrolysed infant formula for two to four weeks. Overfeeding is another cause of regurgitation, and parents should reduce the volume of feeds to exclude overfeeding as a possible cause of reflux episodes. $^{2}$

\section{Postural therapy}

In the past, prone and lateral positioning was used to reduce oesophageal exposure to acid. It has since been proved that both positions increase the risk of sudden infant death syndrome. Therefore, these methods are not recommended as a treatment method for GOR or GORD. ${ }^{2,7}$ 


\section{Drug and surgical treatments for GORD}

Drugs that are used to treat GORD include alginate combinations, histamine 2 receptor antagonists, protonpump inhibitors (PPIs) and antacids. Many of these are licensed adult drugs. Gaviscon infant ${ }^{\oplus}$, an alginate combination, is licensed for use from birth, and has been proven to be effective in reducing the number of regurgitation and emetic episodes for mild GOR. Infants who do not respond to alginate combinations and dietary changes might benefit from treatment with histamine 2 receptor antagonists, which are effective in reducing acid secretion and esophagitis. However, research regarding the use of PPIs is conflicting. Although it is believed that PPIs reduce gastric acidity, regardless of age, the overall effect on histological aberrations in infants remains unclear. ${ }^{9}$

Children who would benefit from anti-reflux surgery include those with relapsing GORD due to noncompliance of medical treatment or the failure of current medical treatment, those with recurrent respiratory problems, long-term dependence on pharmacotherapy, and pulmonary aspiration of refluxate. Currently, there is considerable debate regarding the use of fundoplications. Although laparoscopic fundoplication in children is considered to be safe and effective, its efficacy in controlling respiratory problems remain unclear..$^{10}$

\section{Thickened infant formula}

Thickened infant formula and thickening agents have long been used as part of a stepwise approach to treating GOR and GORD. However, the use thereof remains controversial due to lack of conclusive evidence regarding efficacy. Current research provides some evidence that the use of thickened infant formula is beneficial in reducing GOR and GORD symptoms. ${ }^{11,12}$ However, a systematic review could not conclude whether a specific thickening agent, such as corn starch or maize flower, locust-bean gum, soy fibre, rice starch or carob-bean gum, is more effective than another. ${ }^{12}$

\section{Efficacy of thickened formula marketed as anti-reflux formula}

A review demonstrated some positive effects that anti-reflux formula, compared to standard infant formula, has on GOR symptoms. These are summarised in Table I. ${ }^{12}$ However, the review reported many limitations, such as overestimation and reporting of positive effects by parents and doctors. The included trials were also sponsored by manufacturers.

Thickened formula can lead to a significant increase in weight gain. Although this is advantageous when infants present with failure to thrive, regular weight monitoring is necessary to identify excessive weight gain if used for extended periods. Feed volumes may be restricted at each feed to prevent undesirable weight gain. ${ }^{12}$ The review also indicates that even though the thickening of food reduce some symptoms of GOR, it may still result in adverse events. Carob thickeners can increase diarrhoea and allergies, while the use of rice-thickened feeds might lead to increased coughing. Furthermore, thickening agents may decrease the absorption of nutrients, such as carbohydrates, fat, calcium, iron, zinc and copper, and alter mucosal and endocrine responses. ${ }^{12}$

\section{Thickened infant formula for GORD}

Evidence regarding the benefits of thickened formula is contradictory. Some studies found no effect on the frequency of regurgitation episodes or oesophageal acid exposure time, while others found that formula with corn starch as a thickening agent reduces the frequency and severity of reflux and vomiting, and may potentially decrease oesophageal acid exposure, as evaluated with $\mathrm{pH}$ monitoring..$^{13}$

Table I: The positive effects of different thickening agents on gastro-oesophageal reflux symptoms ${ }^{12}$

\begin{tabular}{|l|c|c|c|c|c|c|c|}
\hline & \multicolumn{7}{|c|}{ Symptoms of gastro-oesophageal reflux } \\
\hline Thickener & $\begin{array}{c}\text { Increase in } \\
\text { the number of } \\
\text { infants without } \\
\text { regurgitation }\end{array}$ & $\begin{array}{c}\text { Decrease } \\
\text { in vomiting } \\
\text { episodes }\end{array}$ & $\begin{array}{c}\text { Decrease in } \\
\text { regurgitation } \\
\text { episodes }\end{array}$ & $\begin{array}{c}\text { Decrease } \\
\text { in irritability } \\
\text { episodes }\end{array}$ & $\begin{array}{c}\text { Decrease in } \\
\text { crying and } \\
\text { dysphagia }\end{array}$ & $\begin{array}{c}\text { Decrease in } \\
\text { regurgitation } \\
\text { symptoms }\end{array}$ & $\begin{array}{c}\text { Improvement } \\
\text { in reflux index }\end{array}$ \\
\hline Soy fibre & $X$ & - & $X$ & - & - & - & - \\
\hline Carob-bean gum & $X$ & - & $X$ & - & - & - & - \\
\hline Corn flour & - & $X$ & $X$ & - & - & - & - \\
\hline Rice based & - & $X$ & $X$ & - & - & - & - \\
\hline Locust-bean gum & - & - & $X$ & - & - & - & - \\
\hline Corn-starch & - & $X$ & - & $X$ & $X$ & $X$ \\
\hline
\end{tabular}


Table II: Warning signs and signs of complicated gastro-oesophageal reflux disease ${ }^{2}$

\begin{tabular}{|c|c|}
\hline Warning signs & $\begin{array}{l}\text { Signs of complicated gastro- } \\
\text { oesophageal reflux disease }\end{array}$ \\
\hline $\begin{array}{l}\text { Bilious vomiting } \\
\text { Gastrointestinal bleeding } \\
\text { Haematemesis } \\
\text { Haematochezia } \\
\text { Consistently forceful vomiting } \\
\text { Onset of vomiting after six } \\
\text { months of life } \\
\text { Failure to thrive } \\
\text { Diarrhoea } \\
\text { Constipation } \\
\text { Fever } \\
\text { Lethargy } \\
\text { Hepatosplenomegaly } \\
\text { Bulging fontanelles } \\
\text { Macrocephaly or microcephaly } \\
\text { Seizures } \\
\text { Abdominal tenderness or } \\
\text { distension } \\
\text { Documented or suspected } \\
\text { genetic or metabolic syndrome }\end{array}$ & $\begin{array}{l}\text { Oesophagitis } \\
\text { Oesophageal stricture } \\
\text { Barrett's oesophagus } \\
\text { Laryngeal or pharyngeal } \\
\text { inflammation } \\
\text { Recurrent pneumonia } \\
\text { Anaemia } \\
\text { Dental erosion } \\
\text { Feeding refusal } \\
\text { Dystonic neck posturing } \\
\text { (Sandifer syndrome) } \\
\text { Apnoea } \\
\text { Apparent life-threatening events }\end{array}$ \\
\hline
\end{tabular}

\section{Possible adverse effects of using anti-regurgitation formula}

Reduced caloric density, osmolality, protein, calcium and fatty acid content in anti-regurgitation or reflux formula, suggest that such formula is more advantageous than a standard formula with added thickener. ${ }^{7}$ It is possible that thickening agents may decrease the bioavailability of key nutrients by decreasing the intestinal absorption. When formula are thickened with indigestible carbohydrates, such as carob-bean gum, the bioavailability of calcium, iron and zinc is decreased, which is not seen when starch is used. ${ }^{12,13}$

It is the joint recommendation of the North American Society for Pediatric Gastroenterology, Hepatology and Nutrition (NASPGHAN) and the European Society for Paediatric Gastroenterology, Hepatology and Nutrition (ESPGHAN) that the use of thickened formula may decrease visible regurgitation, but does not result in a measurable decrease in the frequency of oesophageal reflux episodes. ESPGHAN and NASPGHAN further recommend that in the absence of complicated GOR, the use of a thickened formula might be advised. If warning signs and signs of complicated GORD (Table II) are present, further investigation is needed. ${ }^{2}$

\section{Commercially available thickened formula}

A number of thickened infant formula is available in South Africa (Table III). Thickening agents include soy fibre, carobbean gum, corn starch, rice and locust-bean gum. Some adverse effects, such as diarrhoea and allergies, have been reported with the use of carob thickener, while rice thickener was found to increase coughing in infants $<24$ months with GORD. ${ }^{12}$

The nutritional composition of all infant formula, including anti-reflux formula, must meet the global standards

Table III. Available anti-regurgitation or reflux formula

\begin{tabular}{|c|c|c|c|c|c|c|}
\hline Class & Brand name & $\begin{array}{c}\text { Thickening agent } \\
\text { used }\end{array}$ & $\begin{array}{l}\mathrm{kcal} / \\
100 \mathrm{ml}\end{array}$ & $\begin{array}{l}\text { Protein source and } \\
\mathrm{g} / 100 \mathrm{ml}\end{array}$ & $\begin{array}{l}\text { Carbohydrates } \\
\text { and } \mathrm{g} / 100 \mathrm{ml}\end{array}$ & Additives \\
\hline \multirow[t]{5}{*}{$\begin{array}{l}\text { Anti-reflux } \\
\text { formula }\end{array}$} & $\operatorname{Nan} A R^{\circledR}$ & Precooked corn starch & 67.0 & $\begin{array}{c}\text { Demineralised whey } \\
30: 70 \text { whey- } \\
\text { dominant, } 1.24\end{array}$ & $\begin{array}{l}\text { Lactose, potato and } \\
\text { corn starch, } 7.7\end{array}$ & - \\
\hline & $\begin{array}{l}\text { Novalac AR } 1^{\circledR} \\
\text { Novalac AR } 2^{\circledR}\end{array}$ & $\begin{array}{l}\text { Corn starch (thickens } \\
\text { at gastric } \mathrm{pH} \text { ) }\end{array}$ & $\begin{array}{l}1: 66.0 \\
2: 64.3\end{array}$ & $\begin{array}{c}\text { Skim milk, } \\
\text { 80:20 casein- } \\
\text { dominant, 1:1.6, } \\
2: 1.7\end{array}$ & $\begin{array}{l}\text { Lactose and corn } \\
\text { starch, } 7.4\end{array}$ & $\begin{array}{l}\text { Long-chain } \\
\text { polyunsaturated fatty } \\
\text { acids }\end{array}$ \\
\hline & $\begin{array}{l}\text { Novalac } \mathrm{AR}^{\circledR} \\
\text { Digest }^{\circledR}\end{array}$ & $\begin{array}{l}\text { Locus-bean gum and } \\
\text { starch }\end{array}$ & 62.8 & $\begin{array}{c}100 \% \text { partially } \\
\text { hydrolysed whey, } \\
1.5\end{array}$ & $\begin{array}{l}\text { Maltodextrin and } \\
\text { lactose, } 6.8\end{array}$ & $\begin{array}{l}\text { Long-chain } \\
\text { polyunsaturated fatty } \\
\text { acids }\end{array}$ \\
\hline & $\begin{array}{c}\text { Infacare } \\
\text { Nurture } A R^{\circledast}\end{array}$ & Carob-bean gum & 67.0 & $\begin{array}{c}\text { Skim milk, } \\
\text { 80:20 casein- } \\
\text { dominant, } 1.6\end{array}$ & $\begin{array}{l}\text { Lactose, maltodextrin, } \\
\text { corn syrup solids, } 7.0\end{array}$ & $\begin{array}{c}\mathrm{DHA}^{\mathrm{a}}, \mathrm{AA}^{\mathrm{b}} \text {, and } \\
\text { nucleotides }\end{array}$ \\
\hline & Infacare $A R^{\circledast}$ & $\begin{array}{l}\text { Locus-bean gum (guar } \\
\text { gum, a soluble fibre) }\end{array}$ & 66.0 & $\begin{array}{l}\text { Skim milk, } \\
\text { 80:20 casein- } \\
\text { dominant, } 1.6\end{array}$ & $\begin{array}{l}\text { Lactose, maltodextrin, } \\
\text { corn syrup solids, } 6.8\end{array}$ & - \\
\hline $\begin{array}{l}\text { Thickening } \\
\text { agent }\end{array}$ & Nestargel ${ }^{\circledR}$ & $\begin{array}{l}\text { Carob-bean gum } \\
\text { (carob seed flour) }\end{array}$ & $\begin{array}{c}38.0 \mathrm{kcal} / \\
100 \mathrm{~g} \text { powder }\end{array}$ & $6 \mathrm{~g} / 100 \mathrm{~g}$ powder & $\begin{array}{c}\text { Cellulose } \\
1 \mathrm{~g} / 100 \mathrm{~g} \\
\text { hemicellulose } \\
76.2 \mathrm{~g} / 100 \mathrm{~g}\end{array}$ & - \\
\hline
\end{tabular}


recommended by ESPGHAN. Anti-reflux formula is either cow-milk-based or hydrolysed cow-milk protein, and must contain 1.8-3 g/100 kCal. Soy protein is not indicated for use in anti-reflux formula. ${ }^{14}$

\section{Conclusion}

Gastro-oesophageal reflux is a common and normal physiological process that affects many infants, especially premature infants and neonates. Most cases resolve without treatment, but a few might need medical treatment; either pharmacotherapy or surgery. Thickened formula is often used as a first step in treating complicated GOR. The efficacy and efficiency of these are still debatable, but many parents and physicians find that it is an effective treatment method for mild GOR and GORD. ESPGHAN and NASPGHAN have defined guidelines with regard to the use of thickened formula, but they should not be seen as a substitute for clinical judgment or protocols that are already in place at healthcare institutions. More research is needed to define clear clinical guidelines on the use of thickened infant formula. Research is also needed to compare the use of thickened infant formula to that of pharmacotherapy and surgical treatment.

\section{References}

1. Huang RC, Forbes DA, Davies MW. Feed thickener for newborn infants with gastro-oesophageal reflux. [Cochrane Review]. In: The Cochrane Library, Issue 3, 2002. Oxford: Update Software.

2. Vandenplas $Y$, Rudolph CD, Di Lorenzo C, et al. Pediatric gastroesophageal reflux clinical practice guidelines: joint recommendations of the North American Society for Pediatric Gastroenterology, Hepatology and Nutrition (NASPGHAN) and the European Society for Paediatric Gastroenterology, Hepatology and Nutrition (ESPGHAN). J Pediatr Gastroenterol Nutr. 2009;49(4):498-547.

3. O'Connor NR. Infant formula. Am Fam Physician. 2009;79(7):565-570.

4. Vakil N, van Zanten SV, Kahrilas P, Dent J. The Montreal definition and classification of gastroesophageal reflux disease: a global evidence-based consensus. Am J Gastroenterol. 2006;101(8):1900-1920.

5. Rudolph CD, Mazur LJ, Liptak GS, et al. Guidelines for evaluation and treatment of gastroesophageal reflux in infants and children: recommendations of the North American Society for Pediatric Gastroenterology and Nutrition. J Pediatr Gastroenterol Nutr. 2001;32(Suppl 2):S1-31.

6. Falconer J. GOR and GORD in infants. Community Pract. 2009;82(10):42-43

7. Drug and Therapeutics Bulletin. Managing gastro-oesophageal reflux in infants. BMJ. 2010;341:c4420.

8. Henry SM. Discerning differences: gastroesophageal reflux and gastroesophageal reflux disease in infants. Adv Neonatal Care. 2004;4(4):235-247.

9. Van der Pol RJ, Smits MJ, van Wijk MP, et al. Efficacy of proton-pump inhibitors in children with gastroesophageal reflux disease: a systematic review. Pediatrics. 2011;127(5):925-935.

10. Iwanaka T, Yutaka K, Masahiko S, et al. Laparoscopic fundoplication for gastroesophageal reflux disease in infants and children. Surg Today. 2010;40(5):393-397.

11. Wenzl TG, Schneider S, Scheele F, et al. Effects of thickened feeding on gastroesophageal reflux in infants: a placebo-controlled crossover study using intraluminal impedance. Pediatrics. 2003;111(4 Pt 1):e355-e359.

12. Horvath $A$, Dziechciarz P, Szajewska $H$. The effect of thickened-feed interventions on gastroesophageal reflux in infants: systematic review and meta-analysis of randomized, controlled trials. Pediatrics. 2008;122(6):e1268-1277.

13. Vandenplas $Y$, Salvatore $S$, Hauser $B$. The diagnosis and management of gastrooesophageal reflux in infants. Early Hum Dev. 2005;81(12):1011-1024.

14. Koletzko B, Baker S, Cleghorn G, et al. Global standard for the composition of infant formula: recommendations of an ESPGHAN coordinated international expert group. J Pediatr Gastroenterol Nutr. 2005;41(5):584-599. 